\title{
Indigenous knowledge of shrimps and prawn species and fishing of the Benue and Niger river (middle - belt savannah) - Nigeria.
}

\author{
Okayi . R. G, Solomon .S.G, Ataguba .A.G, Chukwudi .O.P. and Mbata .F.U. \\ Department of Fisheries and Aquaculture, \\ University of Agriculture, P.M.B 2373, Makurdi, Nigeria. \\ Corresponding author email: rgokayi @yahoo.com
}

Tel : +2348054482199 or +2348068078099 .

\begin{abstract}
The study was carried out in 3 - state of Nigeria, Benue, Kogi and Niger with the following towns as the study areas Makurdi, Idah , Ganaja and Jebba. The major objective of this study was to have knowledge on the socio - economic indices, fishing gear, local name and fishing methods involved in shrimp fishing in the 3 states. Data on the socio - economic indices of the fisher folk's were obtained through structured questionnaires and personal interviews. The data obtained revealed that shrimp fishing was mostly the profession of the young persons (Age $21-40$ years) and the educational level of the fisher folks was high in the 3 study area with most of the fisher folks attaining mostly up to secondary school education and tertiary education in the areas. Ganaja having a value of $57.14 \%$ of fisher folks that attained tertiary education, $69.23 \%$ as the highest value of fisher folk's that attain secondary school in Idah and $46.15 \%$ as the highest value of fisher folk's that attain primary school education in Makurdi. The fishing method employed commonly in the areas of study was the use of basket and sticks and the use of fishing traps. The shrimps were sold at varying prices ranging from $\$ 120.00$ per milk cup - $\$ 5,000.00$ for half a big basin in the study areas.
\end{abstract}

Key words:Indigenous knowledge, shrimps, River Niger and River Benue,Nigeria.

\section{INTRODUCTION}

Indigenous knowledge constitutes a communities adaptation to its environment. "Adaptation in this context means the way fisher folk's harness the resources of their environment in order to establish a viable relationship to it. F.A.O. (1997) states that without accurate date on species composition of landings and associated information's on effort, it is impossible to assess the status of the stocks. For management and conservation, indigenous knowledge of species composition and structure is necessary.

In the artisanal fishery, the shrimp species composition is influenced by the gear type and fishing location (F.A.O, 2001). For studies of this nature requiring species inventory, gear that could capture all available species are important. The estuarine prawn Nematopaleamon hastus dominates artisanal catches from coastal waters in estuarines of Cross river, Nigeria together with Penaues notalis. Estuarine prawns usually less than $65 \mathrm{~mm}$ in length are sold dried and locally referred to as 'crayfish'. Dried Nematopalaemon may be cooked whole, but is mostly grinded and used as condiment in local dishes (CERHD, 2007). In freshwater rivers and creeks, macrobrachium fishery predominates. M.felicinum (Niger river prawn), M. vollenhovenii (African river prawn) and M. macrobrachion (Brackish river prawn) dominates the catches of this sector. Other species that can be ranked as important in small scale shrimp sector in the sense that they harvested for selling include; Desmocaris trispinosa (Guinea swamp shrimp), Palaemon maculates (Zaire prawn) and Palaemonetes africanus (Creek shrimp) (CERHD, 2007). Shrimp fishery was also observed in the tropical lagoon, south - western Nigeria. The brackish fern Acrostichum aurem was used as a trap for the harvest of macrobrachium spp. The species observed were Macrobrachium vollenhovenii, Macrobrachium macrobrachion, Penaeus notalis and Batanga lebritonis (Babatunde, 2010). 
Agric. Biol. J. N. Am., 2013, 4(3): 221-226

Tropical penaied shrimps are traditionally exploited in Nigeria by artisanal fishermen and industrially by specialized vessels i.e bottom trawler. The shrimp fishery in Nigeria is dominated by the penaeidae shrimp. The notable specie caught in the coastal area of Nigeria is Penaeus notalis( Farfantepeneaus) also known as the pink shrimp (FAO, 1985).

Traps and basket are usually engaged in macrobracuim fishery. Local shrimping in coastal waters involve the use of uniform trap net designed in semblance of trawl net, the net is passive in nature. The stationary net bears different name amongst the various fishing communities. For instance, in Rivers state, local fishers nick named the trap net "Nkoto" at Mbe Ndoro, in Akwa ibom state the net is called "Esik" (CERHD, 2007).

Nigeria's shrimp fisheries, both industrial and artisanal, are a major source of both direct and indirect employment. This include shrimp capture/production, processing for local and export markets and jobs associated with gear sales/repair and cold storage facilities. Shrimps and shrimp products are the second most important commodity export of Nigeria. FAO (2000c) reports that about half the country total shrimp catch (both large and small scale fishing) is exported.

Crayfish, of which N.hastatus is the major constituent, is an essential food condiment in almost all local dishes in south eastern Nigeria. This fishery supplies the essential ingredient to the area and further north in the country. The market price of this ingredient exhibits wide, yearly, cyclical variations. In the peak of the rainy season, the price can go as high as US $\$ 1.50 / \mathrm{kg}$ in the inland areas of south east Nigeria. In the peak of dry season can be as low as US $\$ 0.80 / \mathrm{kg}$ (Ofor, 2002).

According to the study carried out by Babatunde 2010, in Ago - egun, Ikorodu and along the Lagos lagoon beach, the market price of shrimps and prawn are high compared to meat or fish in the markets in the study area. During the study, while a kilogram of prawn was sold between $\$ 410$ and $\$ 450$, meat price averaged ( $\$ 300$ - 350 ) and fish prices stood at \#250 - 300 per kilogram. Thus weight of the prawn fetched more money (>30\% greater i.e 390.00 ) than fish. These high prices encourage regular and active macrobrachium fishing in Lagos lagoon.

This study aim at having the indigenous knowledge of shrimps in the study areas, their local names, type of gears and fishing methods involved in fishing and also the economic aspect of the shrimps.

\section{MATERIALS AND METHOD}

The study was carried out in 3 - states in Nigeria. Benue, kogi and Niger state with the following towns as the study areas; Makurdi, Idah, Lokoja and Jebba. Information's of fisher folk's related to age, sex, marital status, religion, occupation and educational level was gotten by administering questionnaires and guided interview. Also, method of fishing, gear type in use, fishing period and income range was obtained by personal interview with the fisher folk's.

Identification of gear types used by the fishermen in these area and the local and common names of shrimps/prawns of the areas were gotten through personal contacts and discussion with the fishing families at the fishing sites and fish sellers (mostly women) selling close to the river side. Photograph of gears and shrimps identified were taken by the use of digital camera (Digital ID Camera Model C100-ID). The data was analyzed by finding the percentage value and represented on a bar chart.

\section{RESULT AND DISCUSSION}

From the table 1, the age group that engage mostly in the fishing of shrimps were the age $21-40$ years with value of $78.57 \%$ in Ganaja(Lokoja), $68 \%$ in Jebba(Niger), $53.84 \%$ in Idah and $50.96 \%$ in Makurdi, this date was also illustrated in figure 2. The males engage more in the fishing activities than females with the males showing high percentage values than the females in the study area.

Also, married people engage more in fishing activity more than the single individuals in these areas with age group $21-40 y r s$ and $41-60 y r s$ constituting the highest among the married fisher folk's. Most individual that engage in the shrimp fishing are mostly fishermen by occupation as seen in table 1 , with $32.14 \%$ been students in Ganaja.

In contrast to the view that the standard of education of fisher folks could be low, the data obtained in this study showed that the educational level of fisher folk's in these areas were high with most of the fisher folk's attaining mostly up to secondary school education and tertiary education in the study areas with Ganaja having the highest value of $57.14 \%$ for fisher folk's that have attained tertiary education, $69.23 \%$ as the highest value for fisher folk's that attain secondary school education in Idah, $46.15 \%$ as the highest value of fisher folk's that attain primary school education in Makurdi and a total of $47.46 \%$ of fisher folk's that were uneducated in the study areas(see Fig 1). This study compared to that of 
Agric. Biol. J. N. Am., 2013, 4(3): 221-226

Table 1: showing percentage values of Socio - economics of the fisher folks of the areas.

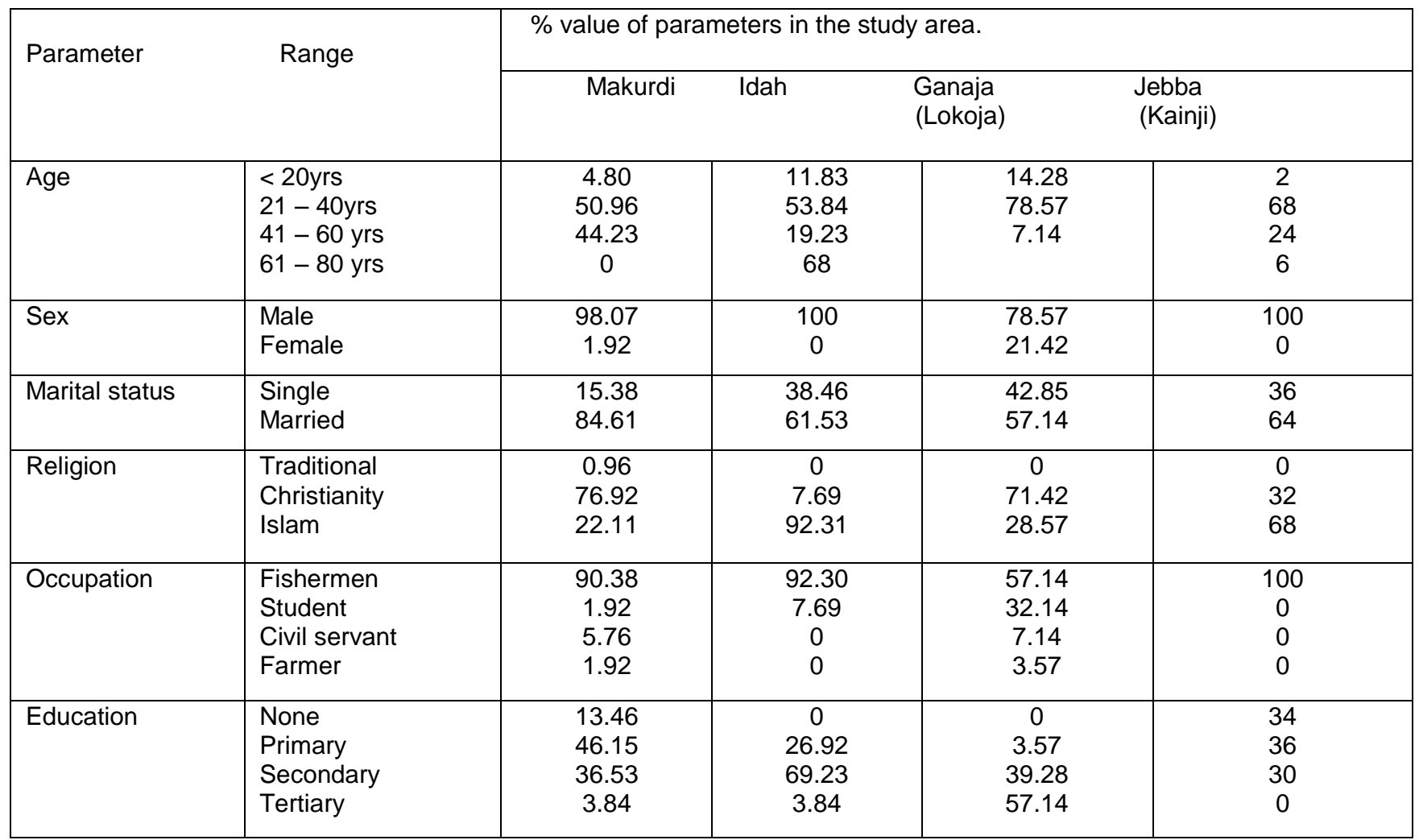

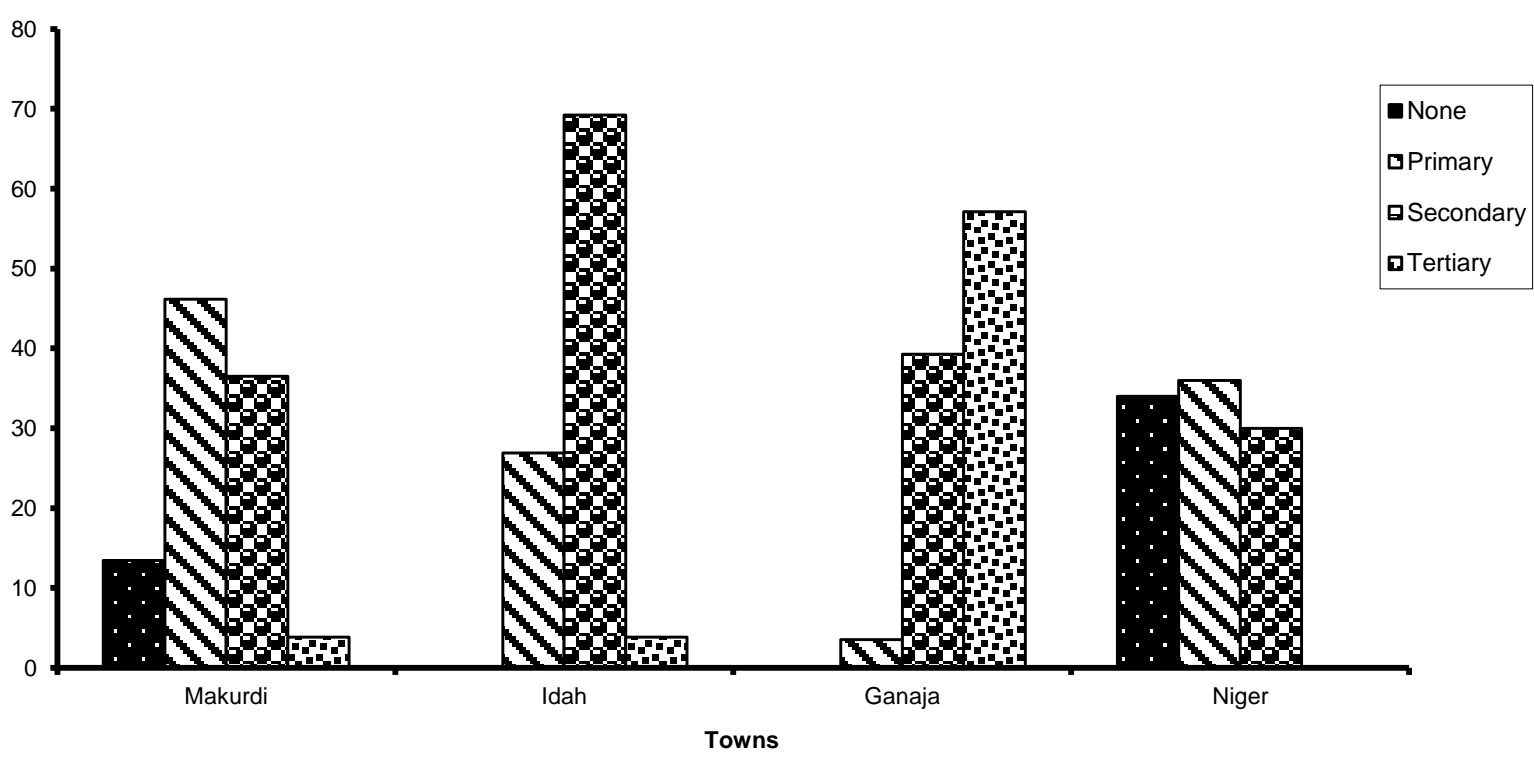

Fig 1: Educational level of fishermen involved in shrimp farming in the lower Benue River and Niger River 
Adeparusi et al. (2003) who reported in their study of artisanal fishers in ilaje, Ondo state, Nigeria also reported that $67.5 \%$ were literate having primary and secondary education or higher education while $32.5 \%$ were illiterate. Also Teitze et al. (2005) reported that farmer had higher levels of education than fisher folks in Malaysia and Bangladesh whereas fisher folks had a higher level of education than agriculturists in India and Senegal. From the result of this study, it shows that fishing activities are been practiced by the respondents on the completion of their secondary school education and been continued by the few fishermen in their tertiary education as a part time activity for the purpose of generating income.

The data in Table:2 was gotten from personal interview with the fisher folk's in the study areas and it was revealed that at Ganaja river side(Lokoja), other species of shrimps and prawns were gotten by setting traps and nets in the water with flowing current. They were also gotten by sinking their boat inside the water for 24 hours with special leaves like palm fronds inside of it and after 24 hours the boat is brought out of the water and the shrimp harvested.

Table 2: Summary of indigenous knowledge traits

\begin{tabular}{|c|c|c|c|c|}
\hline & $\begin{array}{l}\text { Makurdi @ River } \\
\text { Benue }\end{array}$ & $\begin{array}{l}\text { Ganaja River side, } \\
\text { Kogi state }\end{array}$ & $\begin{array}{l}\text { Idah River side, Kogi } \\
\text { state }\end{array}$ & $\begin{array}{l}\text { Jebba lake, Niger } \\
\text { state. }\end{array}$ \\
\hline Shrimp species & $\begin{array}{l}\text { Atya gabonenis, } \\
\text { Macrobrachuim } \\
\text { felicinum }\end{array}$ & $\begin{array}{l}\text { Atya gabonensis, } \\
\text { Macrobrachuim } \\
\text { felicinum }\end{array}$ & Atya gabonensis & Atya gabonensis \\
\hline Common name & $\begin{array}{l}\text { Black crayfish and } \\
\text { brown crayfish. }\end{array}$ & Crayfish & Crayfish & Crayfish \\
\hline Local name & $\begin{array}{l}\text { "Akaande avande", } \\
\text { "Akaande a ishula" } \\
\text { and "Enegenyi" }\end{array}$ & $\begin{array}{l}\text { "Opuru", "Ayolo" and } \\
\text { "Most biller" }\end{array}$ & "Ihia" & "Kachagi" \\
\hline Fishing net(Mesh size) & $3 / 4$ or $5 / 8$ mesh size & Nil & Nil & Nil \\
\hline $\begin{array}{l}\text { Fishing method and } \\
\text { gear used. }\end{array}$ & $\begin{array}{l}\text { Use of fishing net, } \\
\text { trap, the use of basket } \\
\text { and stick. }\end{array}$ & $\begin{array}{l}\text { Use of hands and } \\
\text { basket, sinking of } \\
\text { boats, use of trap and } \\
\text { net. }\end{array}$ & $\begin{array}{l}\text { Use of basket and } \\
\text { bamboo stick. }\end{array}$ & The use of bend stick. \\
\hline Bait used & $\begin{array}{l}\text { Leaves of wood trees } \\
\text { (Kurakya, Akoodu and } \\
\text { lbua wagh) and yam } \\
\text { stems. }\end{array}$ & Palm frond. & Dried yam leaves & Nil. \\
\hline Season Abundant & Dry season & $\begin{array}{l}\text { Dry season and Rainy } \\
\text { season. }\end{array}$ & Rainy season & Dry season. \\
\hline $\begin{array}{l}\text { Price sold in the local } \\
\text { market. } \\
\text { Technology for post } \\
\text { harvest losses. }\end{array}$ & $\begin{array}{l}\# 900-1000 / \mathrm{kg} \\
\$ 5,000 \text { for half a big } \\
\text { basin or small basin. } \\
\text { None }\end{array}$ & \#150.00 per shrimp. & A120.00 per milk cup. & None \\
\hline
\end{tabular}


Agric. Biol. J. N. Am., 2013, 4(3): 221-226

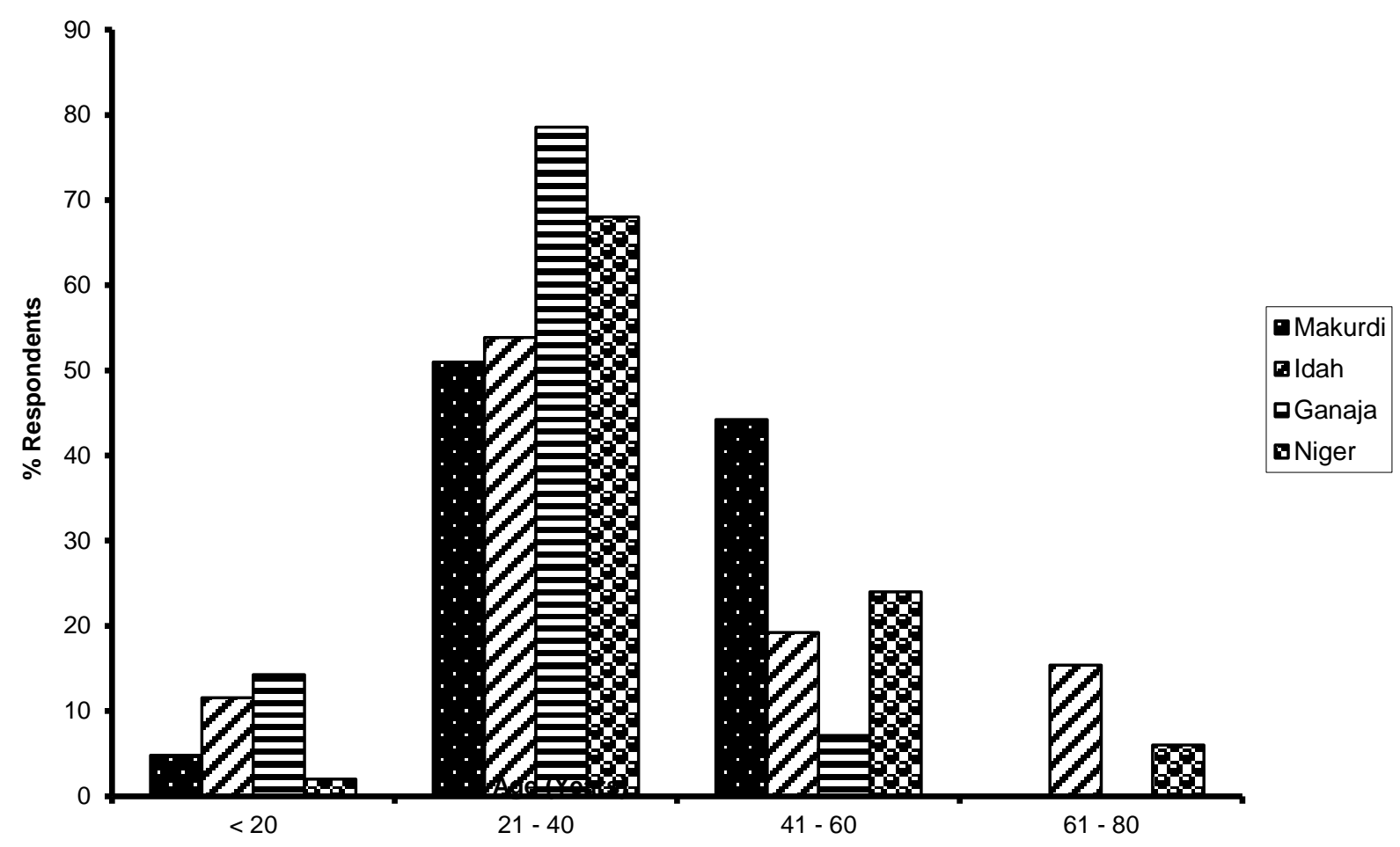

Fig 2: Age grade of fishermen involved in shrimp fishing in the lower Benue River and Niger River

Also the value of these shrimp in these areas in terms of market price varied, in Ganaja(Lokoja)the value of shrimps was due to the fact of the availability of the specie and how much is been requested by the buyer for supply. Also in the study areas, the use of sticks(See Plate 2) and basket for the harvesting were mostly employed in the fishing of the shrimp species Atya gabonensis. The use of traps baited with dry leaves was commonly employed in the fishing of these shrimps in the study areas and this is in line with the findings of Chemonics (2002), who reported that Atya gabonensis are fished using mainly fishing traps, which are usually baited with fish, coconut, cassava, onion and palm kernel nuts around the middle belt areas especially Makurdi. The freshwater prawns are collected from properly baited cage traps and these traps are baited with palm fruits, cassava tubers and onion bulbs and also scooping from under debris and leaf litters using hand baskets. This practice of sampling prawn was also observed in the study carried out in River Orogodo at Abavo, Niger - Delta, southern Nigeria (Arimoro and Meye, 2007).

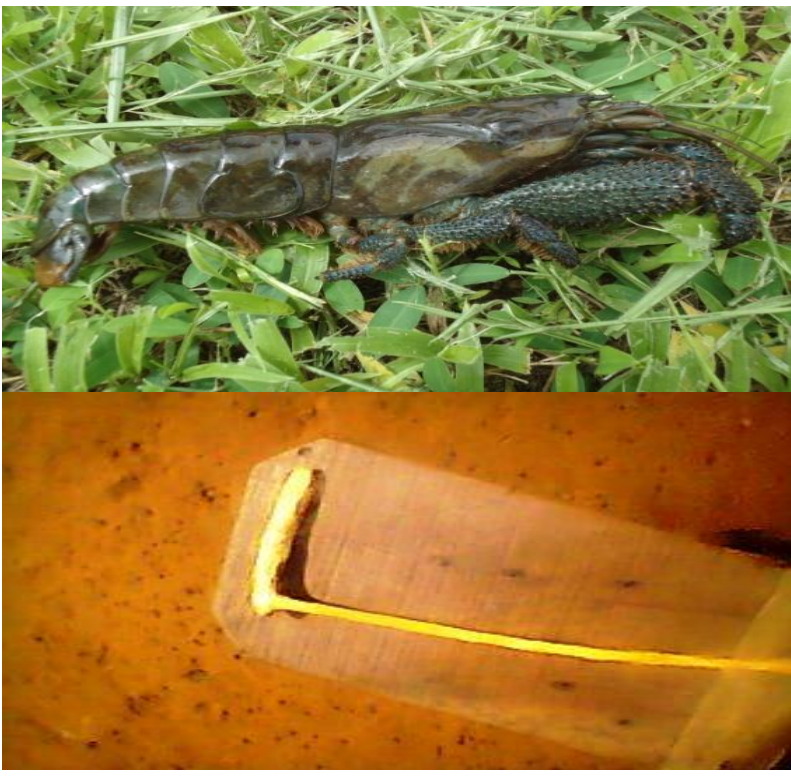

Plate 1: Live Atya gabonensis

Plate 2: Bend stick used for harvesting shrimps

\section{CONCLUSION}

More research should be carried on the culture of these species of shrimps and also their reproductive 
biology known to enhance their candidacy for aquaculture.

\section{ACKNOWLEDGEMENT}

We would like to thank the Competitive Agricultural Research Grant Scheme (CARGS) under the Agricultural Research Council of Nigeria (A.R.C.N.) for providing the research grant. Our sincere gratitude goes to all the collaborating scientist and laboratory technologist of the Department of Fisheries and Aquaculture, University of Agriculture, Makurdi, Benue state, Kogi State University, Anyigba, Kogi state and Freshwater Research Institute,Kianji ,New - Bussa, Niger state.

\section{REFERENCES}

Adeparusi .E.O, Ajibefun .A.I, Akeremale .E.O (2003). Smoke - curing of fish by artisanal fisher folks in ilaje, Ondo state, Nigeria. Assert ser. A 3(4): $101-109$.

Arimoro .O. Francis and Meye .A. Jacob (2007). Some aspect of the biology of Macrobrachium dux (Lenz, 1910) (CRUSTACEA - DECAPODA; NATANTIA) in River Orogodo, Niger - Delta, Nigeria. Department of Zoology, Delta state University. P.M.B 1, Abraka, Nigeria. Acta - boil colomb. Vol. 12. No.2. Bogotul./ Dec 2007.

Babatunde .E.E, (2010). First observation on shrimp fishery using brackish water fern Acrostichum aurem traps in atropical Lagoon, South - western Nigeria. Report and opinion 2010; 2(3): 111 - 115.ISSN: 1553 - 9873.

Center for Environment Human Rights and Development (CEHRD) ( 2007). Small scale shrimp fisheries in Nigeria. A field report based investigation. 17. No 3. Pp $6-7$.
Chemonics International Incorporated (2002). FOR USAID/Nigeria RAISE IQC, Contract No: PCE - 1- 00 - 99 - 00003 - 00. Subsector assessment of the Nigeria shrimp and prawn industry. Agricultural Development Assistance in Nigeria. Order No 812.

F.A.O (1985). A bio-economic model for analysis of sequential artisanal and industrial fisheries for tropical shrimp (with case study of Suriname shrimp fisheries) FIPP/FIRM/T270.FAO Technical paper, pp: 1- 46.

F.A.O (1997). Review of the state of the world fishery resources: Marine fisheries: F.A.O Fisheries circular. No $920 \mathrm{FIRM} / \mathrm{C} 920$, Rome.

F.A.O (2000c). Nigeria: Fishery country profile. Rome (Available at www.fao.org).

F.A.O, 2001; Tropical shrimp fisheries and their impact on living resources: shrimp fisheries in Asia: Bangladesh, Indonesia and the Philippines; in the near east: Bahrain and Iran; in Africa: Cameroon, Nigeria and the United Republic of Tanzania; in Latin America: Colombia, Costa Rica, Cuba, Trinidad and Tobago and Venzuela.FAO Fisheries circular. No. 974. Rome, FAO, 378pp.

Ofor .C.C. (2002). Exploitation rate and by - catch of Nematopalaemon hastatus (Crustacea: Palaemonidae)(Aurivillius, 1898) fishery in the Cross River Estuary, Nigeria. Journal of Aquatic sciences 17(1): 13 - 16 (2002).

Teitze .U, Lash .R, Thomsen .B, Rihan .D (2005). Economic performance and fishing efficiency of marine capture fisheries. FAO Fish. Tech. Pap. No. 482. FAO, Rome, pp:68 